\title{
Isolation and Characterization of Multidrug Resistant Enterobacteriaceae in Urine Sample of Patients Suffering from Urinary Tract Infection with Diabetes and Nephropathy
}

\author{
Nazmul Ahsan ${ }^{1}$, Monzilur Rahman ${ }^{1}$, Md. Nazrul Islam ${ }^{2}$ and Anwarul Azim Akhand ${ }^{1}$ \\ ${ }^{1}$ Department of Genetic Engineering and Biotechnology, University of Dhaka, Dhaka-1000, Bangladesh. \\ ${ }^{2}$ Clinical Microbiology and Immunology Laboratory, LSSD, icddr,b, Moakhali, Dhaka-1212, \\ Bangladesh
}

Received: January 04, 2021; Accepted: May 26, 2021; Published (web): June 20, 2021)

\begin{abstract}
Multidrug-resistant (MDR) organisms are spreading widely and becoming an issue of utmost importance to deal with. In the current study, ten urine samples from diabetic patients suffering from multiple complications, including urinary tract infection (UTI) and nephropathy were investigated. Antibiogram assays of the bacterial isolates from collected samples demonstrated resistance against most of the antibiotics tested. Further studies were conducted to determine the types of resistant bacteria that caused UTI. Analyzing the 16S rDNA sequence and phylogenetic tree, 3 isolates were identified as Escherichia coli, 5 as Klebsiella pneumoniae and the rest 2 as Enterobacter asburiae. The findings of this research indicate the necessity of urgent attention to find an effective alternative drug for treating infections caused by these resistant isolates.
\end{abstract}

Key words: UTI, MDR, Enterobacteriaceae, Antibiogram

\section{INTRODUCTION}

Every year about 150 million people are affected by urinary tract infections (UTIs) worldwide. ${ }^{1}$ UTIs are the most common infection in females, although the male is also affected with lower frequency. ${ }^{2}$ Bacteria are the major causative agent of UTIs, and the most commonly found bacteria in the process are Escherichia coli, K. pneumoniae, and Enterobacter spp. ${ }^{3}$

Antimicrobial resistance is an increasing threat posing serious health concerns. Infectious diseases that were previously treatable with antibiotics are often not cured presently with those antibiotics any more. As a result, mortality, morbidity and overall health care cost are rising. ${ }^{4}$ Bacteria adapt various genetic and biochemical mechanisms to survive

Correspondence to: Nazmul Ahsan

Tel.: +8802-9661920/7822 (off.), +88-02-01718340750;

E-mail: nahsan@du.ac.bd

Dhaka Univ. J. Pharm. Sci. 20(1): 87-93, 2021 (June)

DOI: https://doi.org/10.3329/dujps.v20i1.54036 against new antibiotics. ${ }^{5}$ Resistant strains of bacteria are continuously evolving by spreading antibiotic resistance genes through mobile genetic elements such as plasmids, transposons and integrons. ${ }^{6-8}$ Therefore, it is important to assess routinely whether the bacterial strains develop any resistance against available antibiotics. This would help to address the challenges of treating indigenous diseases caused by Multidrug-Resistant (MDR) bacteria and to discover new treatment options by studying the resistance mechanism.

The UTI patients who remain unresponsive to various antibiotics have been shown to respond effectively against polymyxins and colicins. ${ }^{9-11}$ Polymyxins are known to represent the most used antimicrobial options against carbapenem-resistant $K$. pneumoniae. Indeed, polymyxin $\mathrm{E}$ (colistin) has been considered as a last resort antimicrobial agent to fight against MDR K. pneumoniae infections. ${ }^{11}$ However, in many cases especially in diabetic neuropathy and 
nephropathy, this drug could not be prescribed due to its possible adverse renal and neurological effects. ${ }^{12,13}$ As a result, more analysis and care should be taken while prescribing these drugs to diabetic patients. ${ }^{14} \mathrm{~A}$ recent report of colistin-resistant $K$. pneumoniae isolate also raise concern for limiting further antimicrobial treatment options in these type of infections. ${ }^{15}$

In the current study, patients suffering from urinary tract infection along with diabetes and showing unresponsiveness to several antibiotic drugs were investigated for the presence of MDR bacteria. The 16S rDNA gene was used for the identification of bacteria for phylogenetic studies. ${ }^{16}$ Besides highly conserved sites were used to design primer, and $16 \mathrm{~S}$ rDNA gene which contains hypervariable regions were used to compare bacteria and their identification. ${ }^{17-18}$ Other DNA regions were also used for phylogenic relation prediction. ${ }^{19-20}$

Isolation and characterization of the MDR bacteria revealed the nature of drug resistance in the patient. This study analyzed resistance patterns of MDR bacteria, identified MDR bacteria and established their phylogenetic relationship.

\section{MATERIALS AND METHODS}

Collection of urine samples and culture: For sample collection, we choose 10 UTI patients suffering from diabetes and nephropathy and were unresponsive to antibiotics treatment. Clean-catch midstream urine samples were collected using sterile wide-mouth glass containers. Samples were plated on Nutrient agar and MacConkey agar media (Hi media, India) using calibrated wire loops and then incubated aerobic atmosphere at $37^{\circ} \mathrm{C}$ for 24 hours. A significant infection was considered if urine cultures yield $>10^{5}$ colony-forming units $(\mathrm{CFU} / \mathrm{ml})$. The pure culture was preserved for further use. The individual bacterial strain was characterized by visual observation of the colony and also by gram staining and other tests with standard protocol. ${ }^{21}$

Antibiotic susceptibility testing: Antimicrobial susceptibility testing was done on Mueller-Hinton agar plate (Oxoid, England) using Kirby Bauer disk diffusion method. ${ }^{22}$ Commercially available discs of amikacin, ampicillin, azithromycin, carbenicillin, cefepime, cefixime, cefotaxime, ceftazidime, ceftriaxone, cefuroxime, ciprofloxacin, colistin, cotrimoxazole, gentamicin, imipenem, lomefloxacin, mecillinam, meropenem, netilmicin, nitrofurantoin, norfloxacin, piperacillin+tazobactam, polymyxin B (300 U), and tobramycin were used. The resistance and susceptibility of antibiotics were determined according to the Clinical and Laboratory Standards Institute (CLSI) guidelines.

Identification of bacteria using 16S rDNA sequencing: A partial sequence of $16 \mathrm{~S}$ rDNA was amplified for each isolate, using Polymerase Chain Reaction (PCR). To do so, a colony was picked from the solid plate culture of bacteria and was suspended into nanopure water. The cell suspension was boiled for 5 minutes at $100^{\circ} \mathrm{C}$. The boiled cell suspension was centrifuged at $5,000 \mathrm{rpm}$ for 5 minutes. The supernatant was taken and was used as a template for PCR. The primer pair (27 F-AGA GTT TGA TCM TGG CTC AG and 1492 R- CGG TTA CCT TGT TAC GAC TT) was chosen to amplify three hypervariable regions $(\mathrm{V} 1-\mathrm{V} 3)^{23}$ of $16 \mathrm{~S}$ rDNA. PCR amplification was done for 30 cycles and the condition was 1 minute of denaturation at $94^{\circ} \mathrm{C}, 45$ second at $57^{\circ} \mathrm{C}$ for primer annealing, and 2 minutes at $72^{\circ} \mathrm{C}$ for primer extension, followed by a final step at $72^{\circ} \mathrm{C}$ for 10 minutes and cooling to $4^{\circ} \mathrm{C}$. Products were analyzed by electrophoresis in $1.5 \%(\mathrm{w} / \mathrm{v})$ ethidium bromide containing agarose gels. The PCR product was purified and quantified and diluted to the concentration required for DNA sequencing. PCR DNA of all 10 isolates tested was sequenced using cycle sequencing followed by capillary electrophoresis, in the Center for Advanced Research in Sciences (CARS), University of Dhaka. The quality of the sequences was assessed and sequences were stored in fasta format. All sequences were analyzed using the web interface of the blast program. ${ }^{24}$ The sequences were searched against the $16 \mathrm{~S}$ ribosomal DNA database of bacteria and archaea using the Megablast algorithm. Then phylogenetic trees for each isolate were constructed using the Maximum likelihood method, taking the top 10 
sequences returned by the blast result using MEGA version $5 .^{25}$ Analyzing the distant trees, the most closely related sequences were identified for each isolate, and the alignment result was recorded. According to the maximum match the species name was assigned.

\section{RESULTSANDDISCUSSION}

Colony characteristics and structural morphology of bacterial isolates from urine samples. When the bacterial isolates were grown on nutrient agar plates at $37^{\circ} \mathrm{C}$ temperature under aerobic condition, they produced characteristic colony features. The features of their colony and structural morphology are shown in Table 1. All of them were Gram (-) ve and either short rod or rod in shape. The similarities in characteristics were found among isolates-1, 6, 7, 8 and 9; isolates 2, 3 and 10; and isolates 4 and 5 (Table 1).

Table1. Colony characteristics and structural morphology of bacterial isolates.

\begin{tabular}{|c|c|c|c|c|c|c|c|c|c|c|}
\hline \multirow[b]{2}{*}{ Characteristic } & \multicolumn{10}{|c|}{ Isolates } \\
\hline & 1 & 2 & 3 & 4 & 5 & 6 & 7 & 8 & 9 & 10 \\
\hline $\begin{array}{l}\text { Colony } \\
\text { morphology }\end{array}$ & $\begin{array}{l}\text { grayish } \\
\text { white, } \\
\text { circular, } \\
\text { mucoid }\end{array}$ & $\begin{array}{l}\text { white, } \\
\text { circular, } \\
\text { Smooth, } \\
\text { opaque }\end{array}$ & $\begin{array}{c}\text { white, } \\
\text { circular, } \\
\text { Smooth, } \\
\text { opaque }\end{array}$ & $\begin{array}{l}\text { opaque, } \\
\text { grey, } \\
\text { smooth, } \\
\text { mucoid }\end{array}$ & $\begin{array}{l}\text { grey, } \\
\text { smooth, } \\
\text { convex, } \\
\text { mucoid }\end{array}$ & $\begin{array}{l}\text { grayish } \\
\text { white, } \\
\text { circular, } \\
\text { mucoid }\end{array}$ & $\begin{array}{c}\text { grayish } \\
\text { white, } \\
\text { circular, } \\
\text { mucoid }\end{array}$ & $\begin{array}{c}\text { grayish } \\
\text { white, } \\
\text { circular, } \\
\text { mucoid }\end{array}$ & $\begin{array}{c}\text { grayish } \\
\text { white, } \\
\text { circular, } \\
\text { mucoid }\end{array}$ & $\begin{array}{l}\text { grayish } \\
\text { white, } \\
\text { circular, } \\
\text { opaque }\end{array}$ \\
\hline Gram & Gram & Gram & Gram & Gram & Gram & Gram & Gram & Gram & Gram & Gram \\
\hline staining & -ve & -ve & -ve & -ve & -ve & -ve & -ve & -ve & -ve & -ve \\
\hline Shape & $\begin{array}{l}\text { straight } \\
\text { rod }\end{array}$ & $\begin{array}{c}\text { short } \\
\text { rod }\end{array}$ & $\begin{array}{c}\text { Short } \\
\text { rod }\end{array}$ & bacilli & bacilli & $\begin{array}{l}\text { Straight } \\
\text { rod }\end{array}$ & $\begin{array}{l}\text { straight } \\
\text { rod }\end{array}$ & $\begin{array}{l}\text { straight } \\
\text { rod }\end{array}$ & $\begin{array}{l}\text { straight } \\
\text { rod }\end{array}$ & $\begin{array}{l}\text { short } \\
\text { rod }\end{array}$ \\
\hline Motility & $\begin{array}{c}\text { Non } \\
\text { motile }\end{array}$ & motile & motile & $\begin{array}{c}\text { Non } \\
\text { motile }\end{array}$ & $\begin{array}{c}\text { Non } \\
\text { motile }\end{array}$ & $\begin{array}{c}\text { Non } \\
\text { motile }\end{array}$ & $\begin{array}{c}\text { Non } \\
\text { motile }\end{array}$ & $\begin{array}{c}\text { Non } \\
\text { motile }\end{array}$ & $\begin{array}{c}\text { Non } \\
\text { motile }\end{array}$ & motile \\
\hline
\end{tabular}

Table 2. Antibiogram of isolates obtained from urine samples of UTI patients suffering from diabetes and nephropathy.

\begin{tabular}{|c|c|c|c|c|c|c|c|c|c|c|c|c|c|c|c|c|c|c|c|c|c|c|c|c|}
\hline \multicolumn{25}{|c|}{ Name of the antibiotics } \\
\hline$\frac{\mathscr{U}}{\frac{\tilde{U}}{c}}$ & 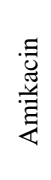 & 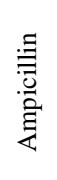 & 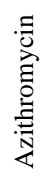 & 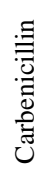 & 芯 & 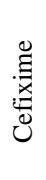 & 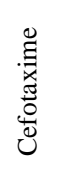 & 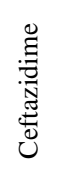 & 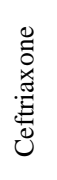 & 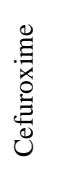 & 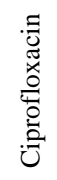 & : & 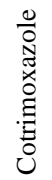 & 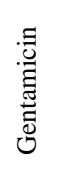 & 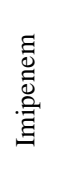 & 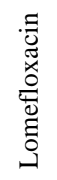 & 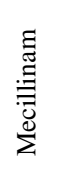 & 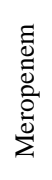 & 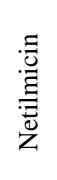 & 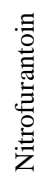 & 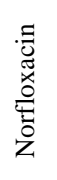 & 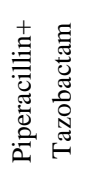 & 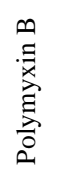 & 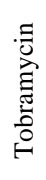 \\
\hline 1 & $\mathrm{~S}$ & $\mathrm{R}$ & $\mathrm{S}$ & $\mathrm{R}$ & $\mathrm{R}$ & $\mathrm{R}$ & $\mathrm{R}$ & $\mathrm{R}$ & $\mathrm{R}$ & $\mathrm{R}$ & $\mathrm{R}$ & $\mathrm{S}$ & $\mathrm{R}$ & $\mathrm{R}$ & $\mathrm{S}$ & $\mathrm{R}$ & $\mathrm{R}$ & $\mathrm{S}$ & $\mathrm{R}$ & $\mathrm{R}$ & $\mathrm{R}$ & $\mathrm{R}$ & $\mathrm{S}$ & $\mathrm{R}$ \\
\hline 2 & $\mathrm{R}$ & $\mathrm{R}$ & $\mathrm{R}$ & $\mathrm{R}$ & $\mathrm{R}$ & $\mathrm{R}$ & $\mathrm{R}$ & $\mathrm{R}$ & $\mathrm{R}$ & $\mathrm{R}$ & $\mathrm{R}$ & $\mathrm{S}$ & $\mathrm{R}$ & $\mathrm{R}$ & $\mathrm{S}$ & $\mathrm{R}$ & $\mathrm{S}$ & $\mathrm{R}$ & $\mathrm{R}$ & $\mathrm{R}$ & $\mathrm{R}$ & $\mathrm{R}$ & $\mathrm{S}$ & $\mathrm{R}$ \\
\hline 3 & $\mathrm{R}$ & $\mathrm{R}$ & $\mathrm{R}$ & $\mathrm{R}$ & $\mathrm{R}$ & $\mathrm{R}$ & $\mathrm{R}$ & $\mathrm{R}$ & $\mathrm{R}$ & $\mathrm{R}$ & $\mathrm{R}$ & $\mathrm{S}$ & I & $\mathrm{S}$ & $\mathrm{R}$ & $\mathrm{R}$ & $\mathrm{S}$ & $\mathrm{R}$ & $\mathrm{R}$ & $\mathrm{R}$ & $\mathrm{R}$ & $\mathbf{I}$ & $\mathrm{S}$ & $\mathrm{R}$ \\
\hline 4 & $\mathrm{R}$ & $\mathrm{R}$ & $\mathrm{R}$ & $\mathrm{R}$ & $\mathrm{R}$ & $\mathrm{R}$ & $\mathrm{R}$ & I & $\mathrm{R}$ & $\mathrm{R}$ & $\mathrm{R}$ & $\mathrm{S}$ & $\mathrm{R}$ & $\mathrm{R}$ & $\mathrm{S}$ & $\mathrm{R}$ & $\mathrm{R}$ & $\mathrm{S}$ & $\mathrm{S}$ & I & $\mathrm{R}$ & $\mathrm{R}$ & $\mathrm{S}$ & $\mathrm{R}$ \\
\hline 5 & $\mathrm{~S}$ & $\mathrm{R}$ & I & $\mathrm{R}$ & $\mathrm{R}$ & $\mathrm{R}$ & $\mathrm{R}$ & $\mathrm{R}$ & $\mathrm{R}$ & $\mathrm{R}$ & $\mathrm{R}$ & $\mathrm{S}$ & $\mathrm{R}$ & $\mathrm{R}$ & $\mathrm{S}$ & $\mathrm{R}$ & I & $S$ & $\mathrm{R}$ & $\mathrm{R}$ & $\mathrm{R}$ & $\mathrm{R}$ & $\mathrm{S}$ & $\mathrm{R}$ \\
\hline 6 & $\mathrm{R}$ & $\mathrm{R}$ & $\mathrm{R}$ & $\mathrm{R}$ & $\mathrm{R}$ & $\mathrm{R}$ & $\mathrm{R}$ & $\mathrm{R}$ & $\mathrm{R}$ & $\mathrm{R}$ & $\mathrm{R}$ & $\mathrm{S}$ & $\mathrm{R}$ & $\mathrm{R}$ & $\mathrm{R}$ & $\mathrm{R}$ & $\mathrm{R}$ & $\mathrm{R}$ & $\mathrm{R}$ & $\mathrm{R}$ & $\mathrm{R}$ & $\mathrm{R}$ & $\mathrm{S}$ & $\mathrm{R}$ \\
\hline 7 & $\mathrm{R}$ & $\mathrm{R}$ & $\mathrm{R}$ & $\mathrm{R}$ & $\mathrm{R}$ & $\mathrm{R}$ & $\mathrm{R}$ & $\mathrm{R}$ & $\mathrm{R}$ & $\mathrm{R}$ & $\mathrm{R}$ & $\mathrm{S}$ & $\mathrm{R}$ & $\mathrm{R}$ & $\mathrm{R}$ & $\mathrm{R}$ & $\mathrm{R}$ & $\mathrm{R}$ & $\mathrm{R}$ & $\mathrm{R}$ & $\mathrm{R}$ & $\mathrm{R}$ & $\mathrm{S}$ & $\mathrm{R}$ \\
\hline 8 & $\mathrm{R}$ & $\mathrm{R}$ & $\mathrm{R}$ & $\mathrm{R}$ & $\mathrm{R}$ & $\mathrm{R}$ & $\mathrm{R}$ & $\mathrm{R}$ & $\mathrm{R}$ & $\mathrm{R}$ & $\mathrm{R}$ & $\mathrm{R}$ & $\mathrm{R}$ & $\mathrm{R}$ & $\mathrm{R}$ & $\mathrm{R}$ & $\mathrm{R}$ & $\mathrm{R}$ & $\mathrm{R}$ & $\mathrm{R}$ & $\mathrm{R}$ & $\mathrm{R}$ & $\mathrm{R}$ & $\mathrm{R}$ \\
\hline 9 & $\mathrm{~S}$ & $\mathrm{R}$ & $\mathrm{R}$ & $\mathrm{R}$ & $\mathrm{R}$ & $\mathrm{R}$ & $\mathrm{R}$ & $\mathrm{R}$ & $\mathrm{R}$ & $\mathrm{R}$ & $\mathrm{R}$ & $\mathrm{S}$ & $\mathrm{R}$ & $\mathrm{R}$ & $\mathrm{R}$ & $\mathrm{R}$ & $\mathrm{S}$ & $\mathrm{R}$ & $\mathrm{R}$ & $\mathrm{R}$ & $\mathrm{R}$ & $\mathrm{R}$ & $\mathrm{S}$ & $\mathrm{R}$ \\
\hline 10 & $\mathrm{R}$ & $\mathrm{R}$ & $\mathrm{R}$ & $\mathrm{R}$ & $\mathrm{R}$ & $\mathrm{R}$ & $\mathrm{R}$ & $\mathrm{R}$ & $\mathrm{R}$ & $\mathrm{R}$ & $\mathrm{R}$ & $\mathrm{S}$ & $\mathrm{R}$ & $\mathrm{R}$ & I & $\mathrm{R}$ & $\mathrm{R}$ & I & $\mathrm{R}$ & $\mathrm{R}$ & $\mathrm{R}$ & $\mathrm{R}$ & $\mathrm{S}$ & $\mathrm{R}$ \\
\hline
\end{tabular}

$\mathrm{S}=$ Susceptible, $\mathrm{R}=$ Resistant, $\mathrm{I}=$ Intermediate . 


\section{Bacterial isolates showed resistance against most antibiotics tested. In the antibiotic} susceptibility test, we used 24 different antibiotics. Our result revealed that all of the tested bacteria showed resistance against most of the antibiotics. Only 2 antibiotics (colistin and polymyxin B) were found sensitive to all bacterial isolates except isolate 8 , which showed resistance against all the antibiotics tested. Amikacin, imipenem, mecillinam, meropenem were found relatively sensitive (not so strong effect as colistin) to some isolates. Among the isolates, isolate-1 was found sensitive against 6 antibiotics (amikacin, azithromycin, colistin, imipenem, meropenem and polymyxin B), isolate-2 against 4 antibiotics (colistin, imipenem, Mecillinam, and polymyxin B), isolate- 3 against 4 antibiotics (colistin, gentamycin imipenem, and polymyxin B) isolate-4 against 5 antibiotics (colistin, imipenem, meropenem, netilmicin, and polymyxin $\mathrm{B}$ ), isolate 9 against 3 antibiotics (amikacin, colistin and polymyxin B), and isolates 6,7 and 10 against only 2 antibiotics (colistin and polymyxin B) (Table 1 and Figure 1). These results revealed that the isolates were MDR in nature and very few antibiotics became sensitive to them. This result indicates difficulties to treat the patients suffering from UTI and other complicy like diabetes and nephropathy.

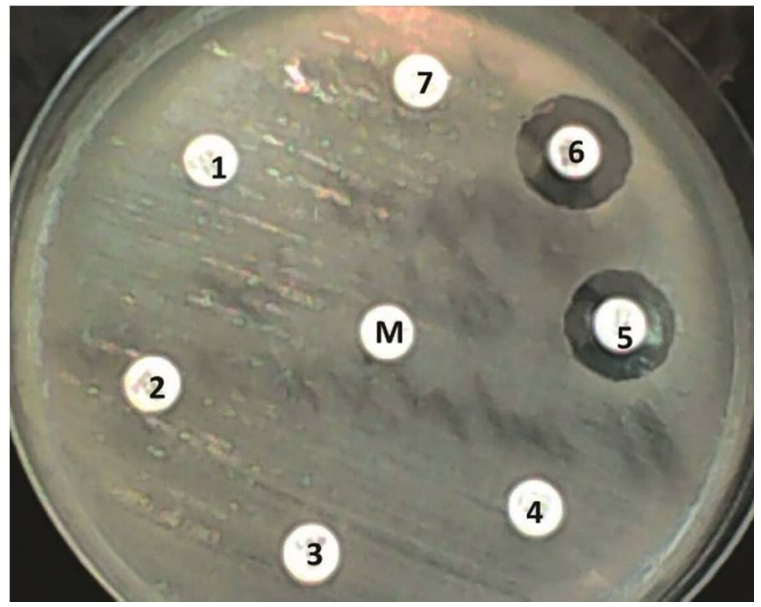

Figure 1. A representative antibiogram figure of the isolate-6. 1Ampicillin; 2- Cefepime; 3- Ceftriaxone; 4- Imipenem; 5Colistin; 6- Polymyxin B; 7- Norfloxacin; M-mock (without antibiotics). This isolates showed sensitivity against only Colistin and Polymyxin B.

PCR and sequencing of $16 S$ rDNA gene. For the amplification of $16 \mathrm{~S}$ rDNA, colony PCR was performed. The gel electrophoresis showed an appropriate band of 514bp (Figure 2). After the purification of the PCR amplified 16S rDNA gene, the sequence for all isolates was obtained through cycle sequencing and capillary electrophoresis. The quality of the sequences was satisfactory. The sequences were then analyzed to identify the isolates.

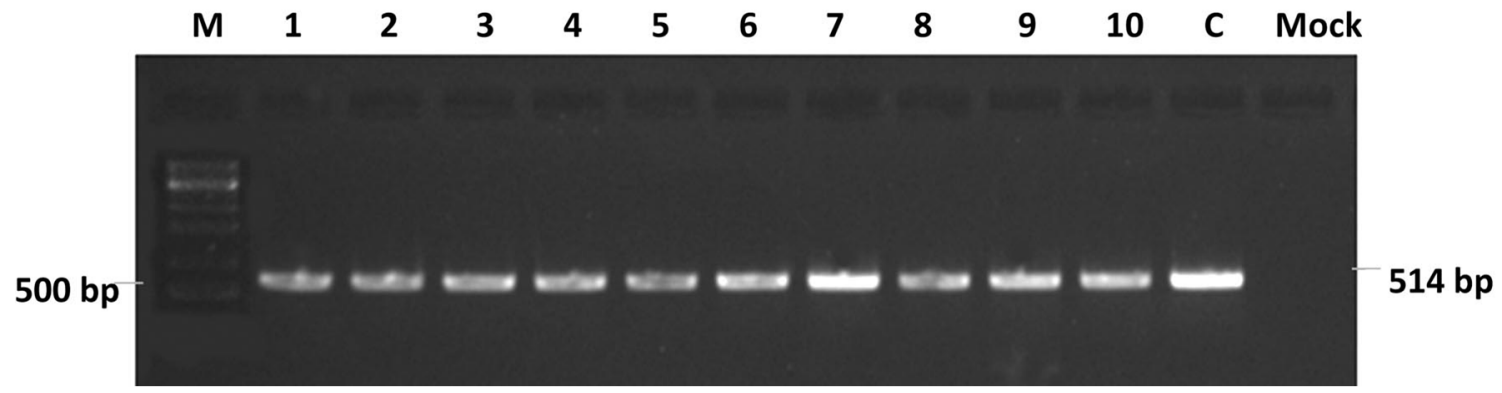

Figure 2. Gel electrophoresis. A purified PCR product of partial 16S rDNA (514 bp) was visualized in gel electrophoresis. M- was for 100 bp DNA ladder, while 1 through 10 were for purified PCR product of the isolates, C-positive control and Mock-PCR without any DNA template. No band in this mock lane indicates absence of DNA contamination in the reagents.

Phylogenetic and 16S rDNA sequence analyses revealed the isolates belonging to Enterobacteriaceae family. Using the blast program, the partial $16 \mathrm{~S}$ rDNA gene sequences were compared against the nucleotide database, and the isolates were identified based on the sequence similarity (Table 3). The phylogenetic tree was constructed by the maximum likelihood method 
using MEGA version 5. Distance tree analysis demonstrated that the isolates $1,6,7,8$ and 9 were closely related to $K$. pneumonia (Table 3 and Figure 3) showing $98 \%$ - $99 \%$ similarity to the reference sequence in the database. Isolate-2, 3 and 10, were closely related to E. coli showing $98 \%, 96 \%$ and $97 \%$ similarity to the reference sequence, respectively.
Isolates 4 and 5 were found to be closely related to $E$. asburiae showing $97 \%$ similarity to the reference sequence. For all the isolates close match was found based on the shortest distance in the phylogenetic tree, and maximum identity, the genus and species were suggested according to the maximum match (Table 3).

Table 3. Blast analysis of partial 16S rDNA sequence searched in nucleotide database.

\begin{tabular}{lllll}
\hline Isolate ID & Query cover & E value & Identity & Species to which the max match belongs to \\
\hline 1 & $100 \%$ & 0.00 & $99 \%$ & Klebsiella pneumoniae \\
2 & $100 \%$ & 0.00 & $98 \%$ & Escherichia coli \\
3 & $100 \%$ & 0.00 & $96 \%$ & Escherichia coli \\
4 & $100 \%$ & 0.00 & $97 \%$ & Enterobacter asburiae \\
5 & $100 \%$ & 0.00 & $97 \%$ & Enterobacter asburiae \\
6 & $100 \%$ & 0.00 & $99 \%$ & Klebsiella pneumoniae \\
7 & $100 \%$ & 0.00 & $98 \%$ & Klebsiella pneumoniae \\
8 & $100 \%$ & 0.00 & $98 \%$ & Klebsiella pneumoniae \\
9 & $100 \%$ & 0.00 & $99 \%$ & Klebsiella pneumoniae \\
10 & $100 \%$ & 0.00 & $97 \%$ & Escherichia coli \\
\hline
\end{tabular}

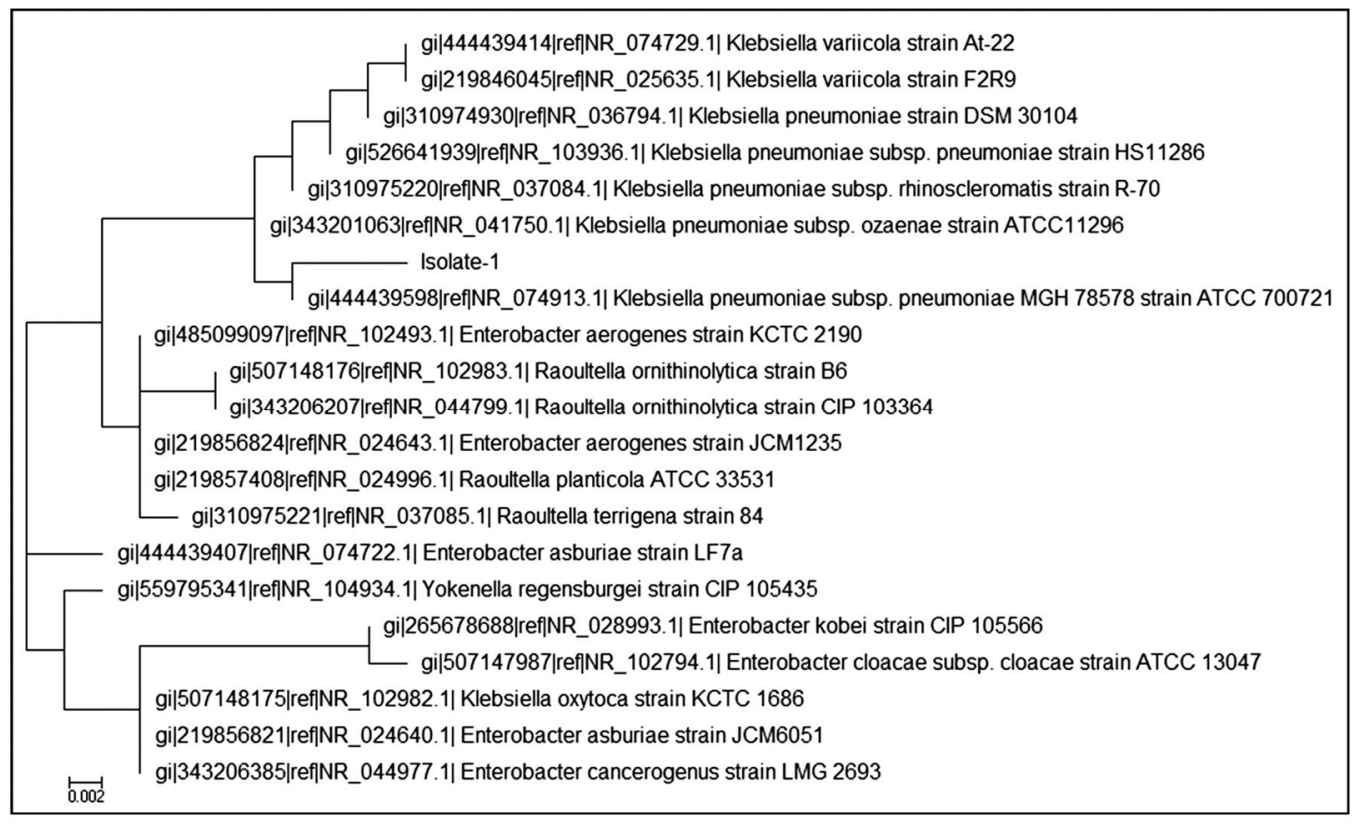

Figure 3. A representative figure of phylogenetic treeanalysis.Isolate-1 was found closely related to Klebsiella pneumonia.

Our results demonstrated that all the MDR strains were resistant to antibiotics like ampicillin, carbenicillin, cefepime, cefixime, cefotaxime, ceftazidime, ceftriaxone, cefuroxime, and ciprofloxacin, cotrimoxazole, lomefloxacin, nitrofurantoin, piperacillin+tazobactam, and tobramycin rendering them obsolete for present-day application. Amikacin, azothomycin, imipenem, 
mecillinam, meropenem remain capable of killing some of the MDR strains. This indicates that resistance to these antibiotics is very much present, but not widespread. Colistin and polymyxin B have shown to be effective against all the bacterial isolates except isolate 8 which is $K$. pneumoniae. However, these antibiotics have been shown to cause neurotoxicity and nephrotoxicity. ${ }^{10,12-15} \mathrm{We}$, therefore, need to develop effective drugs against these kinds of MDR pathogens for better clinical management of the diseases.

Using the $16 \mathrm{~S}$ rDNA gene to identify the isolates, the $\sim 500$ bp sequence was searched in the database, and phylogenetic analyses were conducted. The search result was returned with sequences with a significant match, the E-value for the maximum match was zero for each isolate. Sequences were found $96 \%$ to $99 \%$ identical to at least one sequence in the database. There is always a debate about the exact percentage of identity that a sequence should possess to conclude that it belongs to a particular species. However, more than $\sim 97 \%$ identity is sufficient to decide the species of a bacterium. ${ }^{26}$ The partial 16S rDNA sequence for both the isolates lies very close to so many diverse genus and species that make it hard to reach any conclusion about the species level identity of the isolates. However, in this study species-level identity was suggested based on maximum similarity.

According to the maximum similarity to sequences deposited in the database, isolate- 1 and 6-8 were $K$. pneumoniae, isolate-2, 3 and 10 were $E$. coli, isolate-4 and 5 were E. asburiae. All of them belong to a large family of bacteria, Enterobacteriaceae. So, it can be concluded that MDR bacteria of the Enterobacteriaceae family were responsible for causing multiple antibiotic-resistant urinary tract infections (UTI) along with diabetes, nephropathy and other complications in patients.

In this study, all the strains of bacteria were successfully identified and their phylogenetic relationships were established. From their antibiogram, the resistance profile was also revealed. As these organisms are abundantly associated with human disease, antimicrobial agents have to be available to control them; otherwise, serious epidemics can occur. The resistance genes occur naturally in the bacteria of diverse taxonomical variations. Bacteria are capable of exchanging those genes between the same as well as different species. Moreover, mutations may help to produce more variations capable of defending a wide spectrum of antibiotics. Because of these adaptive mechanisms, bacteria acquire a fighting tendency against any newer antibiotic possible. ${ }^{27}$ Targeted synthetic or antimicrobial agents can be developed specifically to the mechanism of resistance only if the molecular mystery in the organisms is known. This study directs future research on the genome, proteome and metabolome of this Enterobacteriaceae to predict potential therapeutic targets conserved in all three pathogens. Therapeutic targets could be identified through analysis of metabolic pathways, comparison of pathogen and host protein sequences, identification of essential proteins and analysis of protein-protein interactions.

\section{ACKNOWLEDGEMENT}

This work was partially supported by the University Grants Commission (UGC) of Bangladesh.

\section{REFERENCES}

1. Stamm, W.E. and Norrby, S.R. 2001. Urinary tract infections: disease panorama and challenges. J. Infect. Dis. 183, 1-4.

2. Salvatore, S., Salvatore, S., Cattoni, E., Siesto, G., Serati, M., et al. 2011. Urinary tract infections in women. Eur. J. Obstet. Gynecol. Reprod. Biol. 156, 131-136.

3. Gupta, K., Hooton,T.M.andStamm, W.E. 2001. Increasing antimicrobial resistance and the management of uncomplicated community-acquired urinary tract infections. Ann. Intern. Med. 135, 41-50.

4. Lushniak, B.D. 2014. Antibiotic resistance: a public health crisis. Public Health Rep. 129, 314-316.

5. Munita, J.M. and Cesar A. Arias, C.A. 2016. Mechanisms of Antibiotic Resistance. Microbiol Spectr. 4, 10.1128/ microbiolspec.VMBF-00162015. doi: 10.1128/microbiolspec. 
6. Stokes, H.W. and R. Gillings, M.R. 2011. Gene flow, mobile genetic elements and the recruitment of antibiotic resistance genes in Gram-negative pathogens. FEMS Microbiol. Rev. 35, 90-781.

7. Aminov, R. I. 2011. Horizontal gene exchange in environmental microbiota. Front. Microbiol. 2: 158.doi: 10.3389/fmicb.2011.00158.

8. Partridge, S.R., Kwong, S.M,.Firth, N. andJensen, S.O. 2018. Mobile Genetic Elements Associated with Antimicrobial Resistance. Clin. Microbiol. Rev. DOI: 10.1128/CMR.0008817.

9. Zavascki, A. P., Goldani, L. Z., Li, J. and Nation, R. L. 2007. Polymyxin B for the treatment of multidrug-resistant pathogens: A critical review. J. Antimicrob. Chemother. 60, 1206-1215.

10. Arnold, T.M. Polymyxin antibiotics for gram-negative infections.2007. American J. Health-System Pharm. 64, 81926. DOI: 10.2146/ajhp060473.

11. Arnold, R.S., Thom K.A., Sharma, S., Phillips, J.M., Johnson, K. and Morgan, D.J. 2011. Emergence of Klebsiella pneumoniae carbapenemase (KPC)-producing bacteria. South. Med. J. 104, 40-45. doi: 10.1097/SMJ. 0b013e3181fd7d5a.

12. Spapen, H., Jacobs, R., Gorp, V.V., Troubleyn, J. and Honoré, P.M. 2011. Renal and neurological side effects of colistin in critically ill patients. 2011. Ann. Intensive Care. 1, 1-7.

13. Gai, Z., Samodelov1, S.L., Kullak-Ublick, G.A. and Visentin, M. 2019. Molecular mechanisms of colistininduced nephrotoxicity. Molecules. 653, doi: 10.3390/ molecules 24030653 .

14. Karakkattu, J., Mohan, A., James, E. and Kumar, A.2017. Effectiveness and safety of colistin in multi drug resistant urinary tract infections. J. App. Pharm. Sci. 7, 148-152.

15. Capone, A., Giannella, M., Fortini, D., Giordano, A., Meledandri, M., Ballardini, M., et al. 2013. High rate of colistin resistance among patients with carbapenem-resistant Klebsiella pneumoniae infection accounts for an excess of mortality. Clin. Microbiol. Infect. 19, 23-30.

16. Boudewijns, M., Bakkers, J.M., Sturm, P.D.J. and Melchers, W.J.G. 2006. 16S rRNA gene sequencing and the routine clinical microbiology laboratory: a perfect marriage? J. Clin. Microbiol. 44, 3469-3470.

17. Kolbert, C.P. andPersing, D.H. 1999. Ribosomal DNA sequencing as a tool for identification of bacterial pathogens. Curr. Opin. Microbiol. 2, 299-305.
18. Pereira, F., Carneiro, J., Matthiesen, R., van Asch, B., Pinto, N., Gusmao, L. and Amorim, A. 2010. Identification of species by multiplex analysis of variable-length sequences. Nucleic Acids Res. 38, e203-e203.

19. Zeigler, D. R. 2003. Gene sequences useful for predicting relatedness of whole genomes in bacteria. Int. J. Syst.Evolut. Microbiol. 53, 1893-1900.

20. Richert, K., Brambilla, E. andStackebrandt, E. 2007. The phylogenetic significance of peptidoglycan types: Molecular analysis of the genera Microbacterium and Aureobacterium based upon sequence comparison of gyrB, rpoB, recA and ppk and 16S rRNA genes. Syst. Appl. Microbiol. 30, 102108.

21. Yamanaka, K. 2002. The Gram stain. J. Assoc. Rapid Method Auto. Microbiol. 12, 81-90.

22. Barry, A. L. andThornsberry, C. 1985. Susceptibility tests: diffusion test procedures. In: Manual of Clinical Microbiology (Lennette EH, Balows A, Hansler WJ, Shadomy HJ eds.), 4th ed. American Society for Microbiology, Washington DC, pp. 978-987.

23. Chakravorty, S., Helb, D., Burday, M., Connell, N. andAlland, D. 2007. A detailed analysis of $16 \mathrm{~S}$ ribosomal RNA gene segments for the diagnosis of pathogenic bacteria. J. Microbiol. Meth. 69, 330-339.

24. Zhang, Z., Schwartz, S., Wagner, L., and Miller, W. 2000. A greedy algorithm for aligning DNA sequences. J. Comput. Biol. 7, 203-214.

25. Tamura, K., Peterson, D., Peterson, N., Stecher, G., Ne,i M. and Kumar, S. 2011. MEGA5: Molecular evolutionary genetics analysis using maximum likelihood, evolutionary distance, and maximum parsimony methods. Mol. Biol. Evolut. 28, 2731-2739.

26. Drancourt, M., Bollet, C., Carlioz, A., Martelin, R., Gayral, J. andRaoult, D. 2000. 16S ribosomal DNA sequence analysis of a large collection of environmental and clinical unidentifiable bacterial isolates. J. Clin. Microbiol. 38, 36233630.

27. Chan, C. X., Beiko, R. G. and Ragan, M. A. 2011. Lateral transfer of genes and gene fragments in Staphylococcus extends beyond mobile elements. J. Bacteriol. 193, 39643977. 